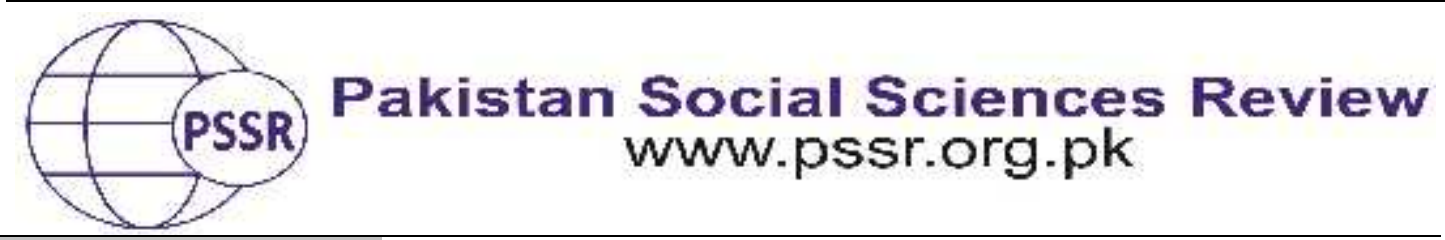

RESEARCH PAPER

\title{
Role of the Mother Tongue in Public and Private Secondary Schools in Sehwan, District Jamshoro: A Comparative Study
}

\author{
Ghulam Mustafa Mallah¹ Dr. Rafique Memon²
}

1. Ph. D Scholar, English Linguistics, Institute of English Language and Literature University of Sindh, Jamshoro, Sindh, Pakistan

2. Professor, Institute of English Language and Literature, University of Sindh, Jamshoro, Sindh, Pakistan

\begin{tabular}{|c|c|}
\hline PAPER INFO & ГRACT \\
\hline $\begin{array}{l}\text { Received: } \\
\text { January 06, } 2021 \\
\text { Accepted: } \\
\text { June 05, } 2021 \\
\text { Online: } \\
\text { June 10, } 2021\end{array}$ & $\begin{array}{l}\text { Several vernaculars are used with five major languages; } \\
\text { Punjabi, Sindhi, Balochi, Pashto and Urdu in Pakistan. } \\
\text { However, the medium of instruction in public and private } \\
\text { secondary schools is used English which no one's Mother } \\
\text { Tongue in Pakistan. The study explores the role of the Mother }\end{array}$ \\
\hline $\begin{array}{l}\text { Keywords: } \\
\text { Bilingual } \\
\text { Education, } \\
\text { Comparative } \\
\text { Study, } \\
\text { Mother Tongue }\end{array}$ & $\begin{array}{l}\text { Tongue as Medium of instruction in public and private } \\
\text { secondary schools in Sehwan, district Jamshoro. The } \\
\text { quantitative approach was used in this study. Simple random } \\
\text { sampling was used in this study. Data were collected from sixty } \\
\text { students and eight teachers by distributing questionnaire. After } \\
\text { collecting the data, it was analyzed in Microsoft Excel for }\end{array}$ \\
\hline $\begin{array}{l}\text { *Corresponding } \\
\text { Author }\end{array}$ & $\begin{array}{l}\text { making pie and bar charts. The study found the important role } \\
\text { of the Mother Tongue as a medium of instruction in Secondary } \\
\text { education in both public and private schools in Sehwan. The } \\
\text { Mother Tongue was found to be used in classroom interaction, } \\
\text { participation in activities in the classroom, clearing the concept } \\
\text { of science and other subjects in the Mother Tongue, students' } \\
\text { performances and language in examinations. Moreover, the } \\
\text { majority of the student and teacher participants suggested that }\end{array}$ \\
\hline $\begin{array}{l}\text { rajama } \\
\text { mail.cc }\end{array}$ & $\begin{array}{l}\text { the Mother Tongue should be the Medium of instruction in } \\
\text { Secondary Schools in Sehwan, district Jamshoro. }\end{array}$ \\
\hline
\end{tabular}

\section{Introduction}

Pakistan is a multilingual country where five major languages: Punjabi, Sindhi, Pashto, Urdu and Balochi, and several local vernaculars are spoken. Urdu is the national language of Pakistan which is the mother tongue about $7 \%$ people in Pakistan (Rahman, 2003) while the official language is English which is no one's mother tongue in Pakistan. Thus, language of instruction has been an issue in taluka Sehwan in Pakistan. 


\section{Literature Review}

Several studies have been conducted to measure the role of the medium of instruction and the right language of instruction in education. Dr. Aijaz Ahmed (2013) conducted a study on the role of the mother tongue used in Pakistani secondary school classrooms where the participants were teachers and students. He found out in his study that the medium of instruction that was being used in the secondary schools was not easily comprehensible for the students. Therefore, the gap between teachers and students remained and created barrier for learning. Vinoba Gautam (2003) conducted a study to investigate the issue of the language of instruction in Delhi, India. He found out that the role of mother tongue in secondary schools was valuable rather than English and children faced problems with English language of instruction. Charles Owu-Ewie (2015) pointed out in his study in Ghana where both the languages, English and Ghanaian languages were used in the classroom as medium of instruction; the students preferred the mother tongue over English and responded in interviews that they comfortably study in their mother tongue rather than a foreign language. Yu-Ying Chang (2010) examined in his study that English language influences on the students and students face difficulties while studying through English medium of instruction.

\section{Private English Medium Schools}

In Sehwan, English medium schools or tuition centers are increasing which claim to make students able to speak English fluently and confidently. Such institutions also claim that the learners can qualify the exams and interviews in English (Rahman, 2002). We can find these institutions situated urban and rural areas where middle and lower middle class get admissions for quality education.

Parents are persuaded to send their children to such institutions because they think that English is considered the key for successful future that everybody wishes for. Rahman (2002) defines there are three main types of English medium schools: (a) state influenced elitist schools, (b) elitist's private schools and (c) is not elitist private schools. Each category has subcategory and the schools which are not of the elites are different in classification. Rahman (2002) further defines that the top private schools are those which are run by the federal government and armed forces. Apart from that, English medium schools, which are operated in garrisons and cantonments, are controlled by the armed forces (Rahman, 2002). Therefore, the state does not have a uniform system of education. In Pakistan, elitists schools are available for rich and powerful people and for common people regular schools are available (Rahman, 2002).

\section{Material and Methods}

Quantitative descriptive approach was used in this study that deals with the observation that is converted into different components of numerical analysis (Maykut and Morehouse, 2002-3). Dornyei (2007) and Cresswell (2003-18) point out 
that quantitative approach predefines the variables that can be assigned by a rational scale of values and can numerically be defined as well. It also calculates and analyzes the data to investigate the relationship between the variables and contains large samples and data sets (Bryman, 2004). Quantitative approach helps to look the results from all sides which are gained from a selected model of the study to the whole population. Four public and four private secondary schools were randomly selected in Sehwan in which the participants were both students as well as teachers. Quantitative questionnaire was used to collect data. The questionnaire was divided into two parts. In the first section, participants' background information was collected and in second section main questions were asked. The data was collected into two phases. Firstly it was collected from the students participants and secondly from the teacher participants. Quantitative descriptive method was used to analyze the data in which pie charts and bar charts are given for discussion.

\section{Results and Discussion}

\section{Part I: Student Participants}

\section{Data Analysis of Student Participants' Background}

First, students' background information was analyzed. Categories of their age, gender, Mother Tongue, monolingual, multilingual or bilingual, Medium of Instruction used in the primary education, and the current Medium of Instruction were made. The table and chart below presents the basic information of the participants.

Table 1

Basic Information of the Student Participants

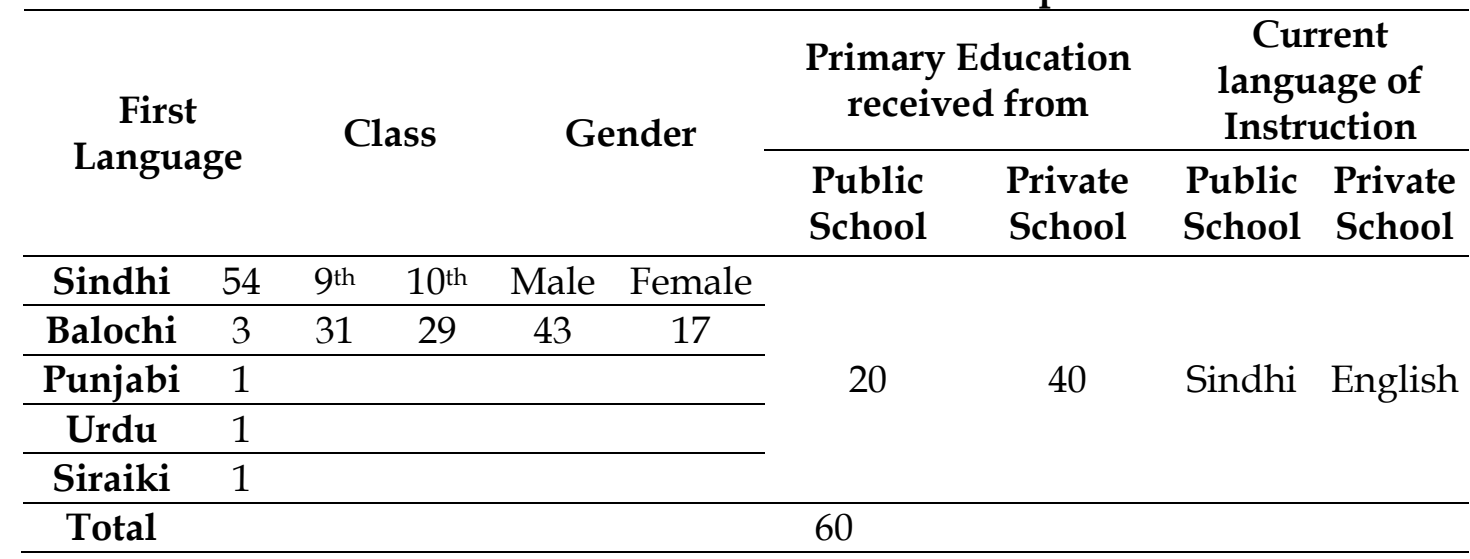

Having given the table of basic information, the following section is further defining the participants' background.

The analysis in the above table shows that the current language of instruction in both public and private schools is Sindhi which is almost everyone's Mother 
Tongue, whereas, the current language of instruction in both private and public schools was English that is not any of the participant's Mother Tongue as well as not the local language of Pakistan. It is clearly shown in the findings that the language of instruction in public schools is the Mother Tongue/local language and in private schools the current language of instruction is English which is foreign language.

Sindhi was the Mother Tongue of the majority of the participants; five percent used Balochi language while Punjabi and Urdu were spoken by $2 \%$ of the participants as their Mother Tongue. Hence, in two public and two private schools, Sindhi was the first language of the majority of the student participants.

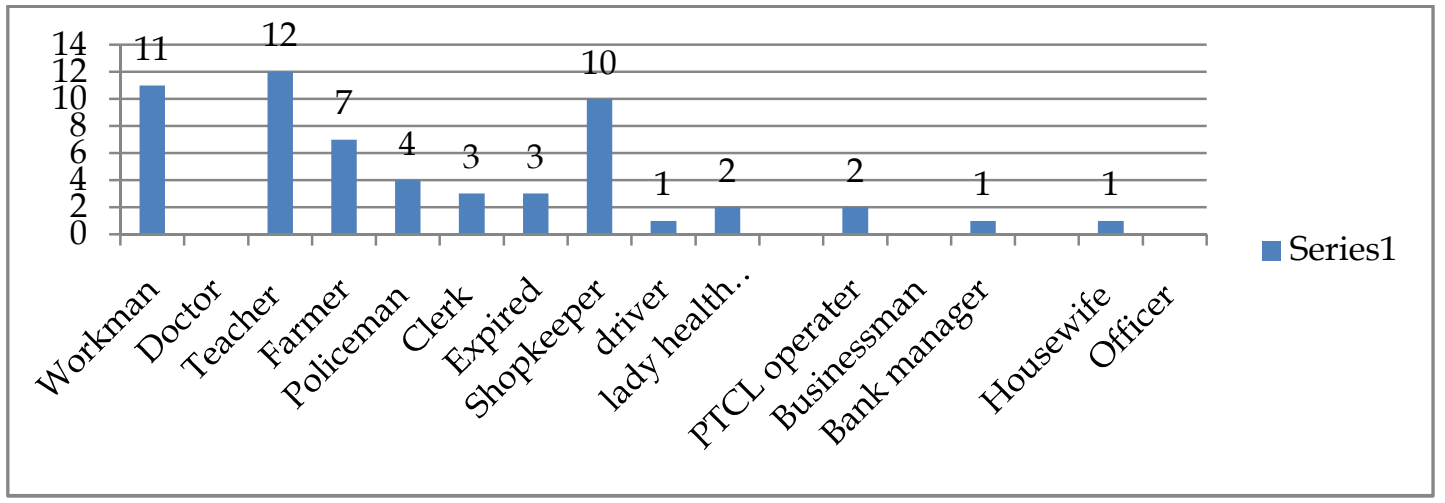

The above diagram shows the responses to the question of the profession of their parents. The majority of the participants' parents were teachers, labors, farmers, policemen, clerks, lady health workers, drivers, bank managers and businessmen. Some of their parents had demised. They all belong to working class in both public and private schools.

The above table shows the educational background of the parents of participants in both public and private schools. The findings show that the majority of the participants put a check on 'No formal degree'. Twenty five percent of the parents had literacy till Matric (10 th standard), there were twenty two percent who had completed intermediate (12th standard), nineteen percent of parents were graduates and very few parents had done post-graduation. This shows the majority had no formal degrees.

Moreover, the background of parents being bilingual/multilingual or monolingual. The majority of the participants informed that their language background was bilingual. Thirty three percent participants responded they were monolingual and seventeen percent said they were multilingual. The language background shows that majority of the participants were bilingual/multilingual who spoke Sindhi, Balochi, Urdu and other indigenous languages of Pakistan. 


\section{Discussion of Findings of Part II (Main Part)}

1. Do you study science subjects through your Mother Tongue?

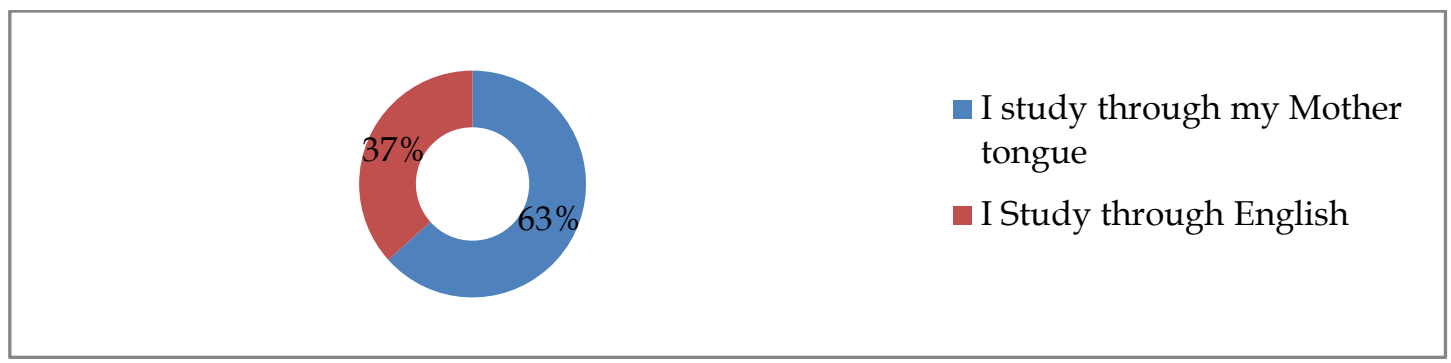

The diagram above shows that the majority of the participants had studied science subjects through their mother tongue. On the other hand, the participants from private schools totally responded that they studied science subjects through English. As it was already shown in the above chart of language of instruction, that in all public schools, the language of instruction was Sindhi, the Mother Tongue of the participants; however, in all private schools the language of instruction was English.

\section{Do you interact with your teacher in English?}

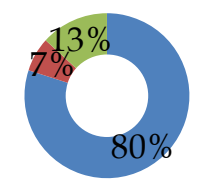

I interact with our teacher in Sindhi

I interact with our teacher in English

The diagram shows the responses which point that the majority of the participants, both in public and private schools, interacted with their teachers in Sindhi rather than English. Only seven percent interaction was done in English. Thirteen percent said that they interacted with their teacher in both Sindhi and English languages.

\section{Do you feel easy when you interact with your teacher in English?}

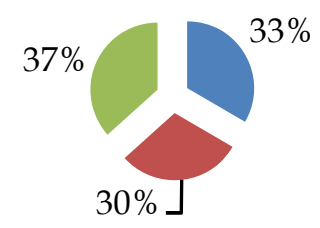

Yes it is easy

In response to the above question, none of participants said that they felt easy interacting in English with their teachers in both public and private schools. It can be clearly seen that students felt easy in their Mother Tongue. It can be said that the 
interaction in the Mother Tongue tends to be successful in the classroom of both in public and private schools of Sehwan.

\section{Do you interact with your teacher in your Mother Tongue?}

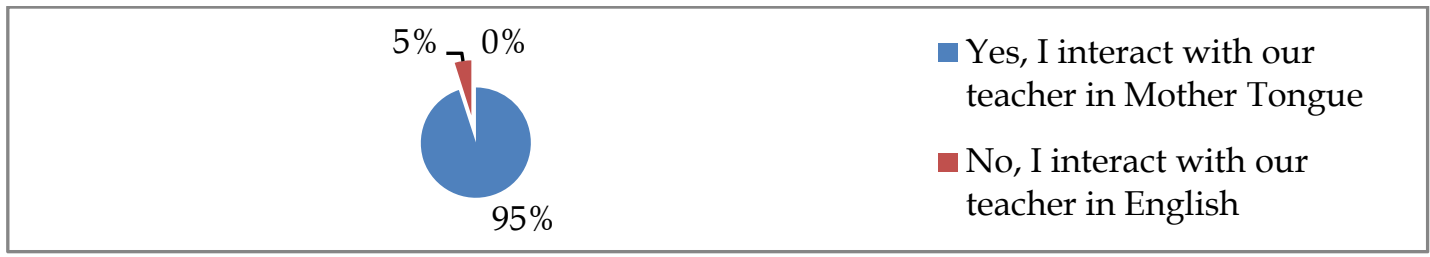

In response to the above asked question in both public and private schools, ninety five percent of the participants informed that they used their Mother Tongue while interacting with their teachers. Only five percent, as the chart shows, said they interacted with their teacher in English. No participant told that he used Urdu while interacting with the teacher in the classroom.

\section{Do you feel easy when you interact with your teacher in Mother Tongue?}

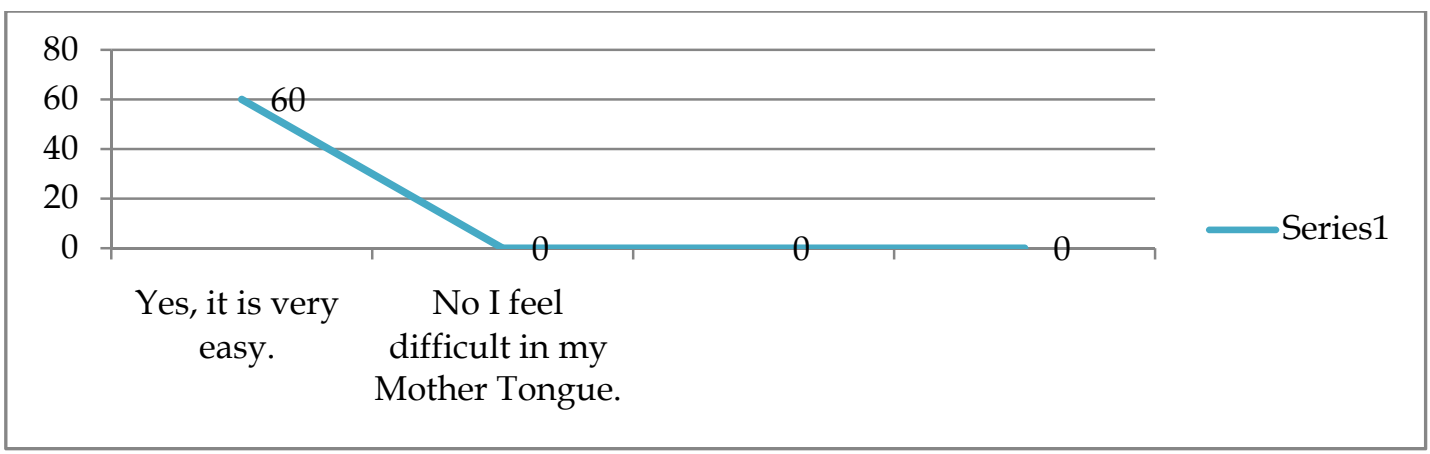

The above diagram shows responses to question number 5 . The findings that in both (public and private schools) show, the majority of the participants put a check on 'It is difficult in front of the other students'. That means that they may not have been able to interact with their teacher in English easily and, especially, they may have felt difficult in front of the other students. As the diagram shows that thirty percent of the participants felt difficult to interact in English and thirty three percent responded that they felt easy while they interacted with their teacher in English.

6. Does your teacher use English while explaining science and other topics in the classroom?

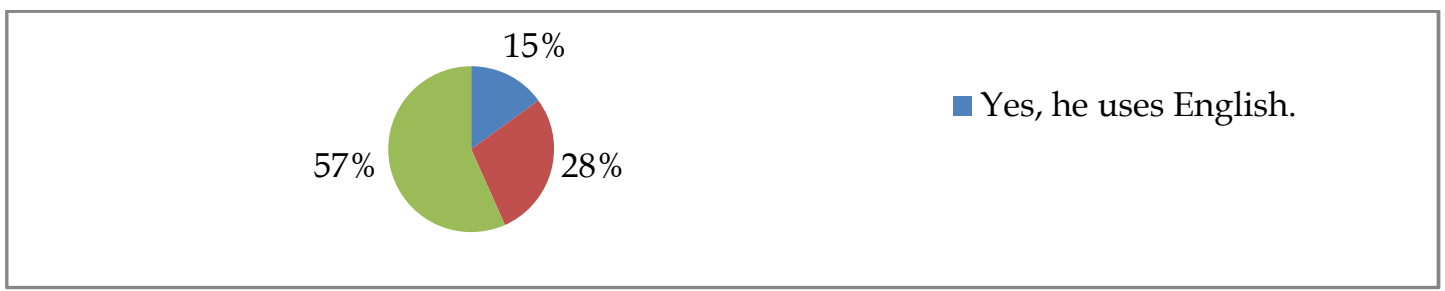


In response to the above asked question, the majority (fifty seven percent) of the participants in both public and private schools responded that their teachers used both languages i.e. Sindhi and English, to explain science and other topics in the classroom. Twenty eight percent shared that the teachers used the Mother Tongue in the classroom and fifteen percent said that the teacher used English while explaining science and the other topics.

7. In which language of instruction, it is easy to understand science and other topics?

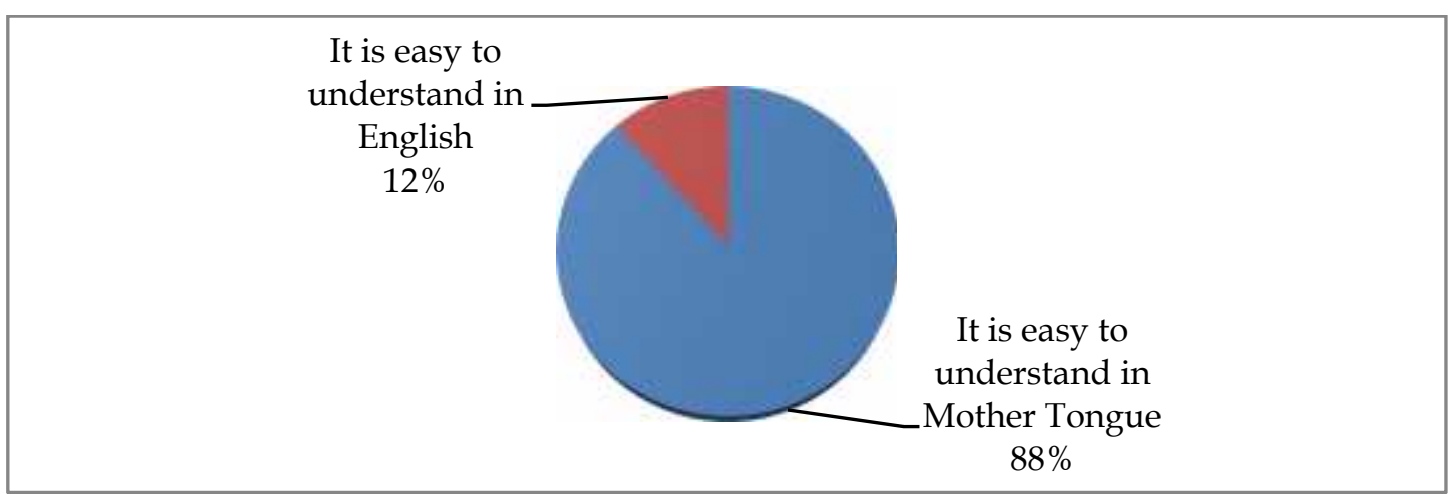

When the participants were asked through which language they comprehend science and other topics easily, eighty eight percent responded that they understood through their Mother Tongue. On the other hand, the rest of the participants responded that it was easy for them to understand science and other topics in the Mother Tongue in both public and private schools.

\section{Do you participate when English is used in the classroom?}

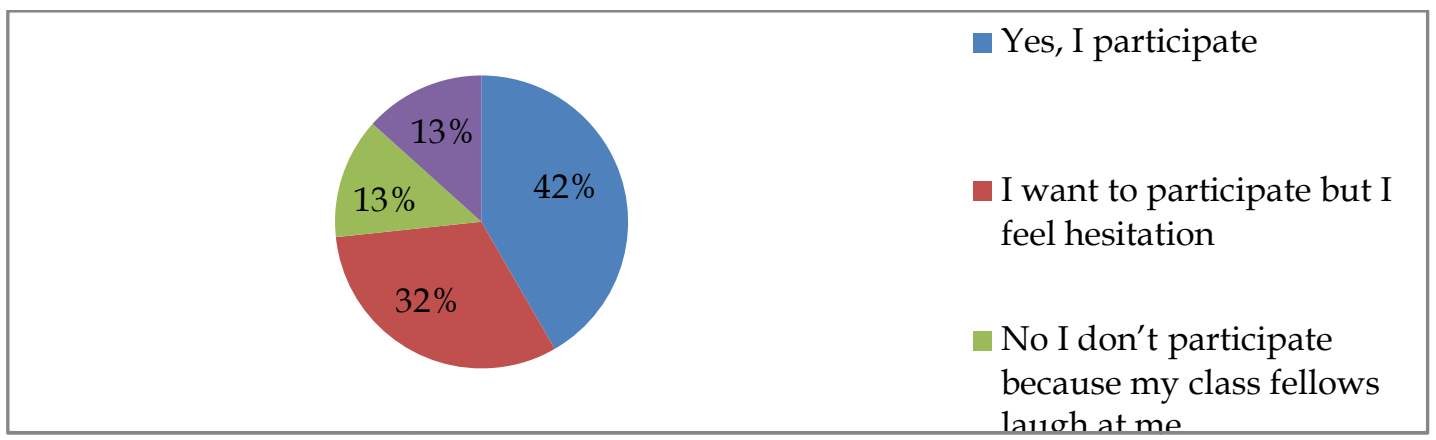

In response to this question, the majority of the participants both from public and private schools responded that they participated in discussion in which English is used. However, thirty two percent said that they wanted to participate but they felt hesitation in front of other students. Thirteen percent opted out of the option 'No, I don't participate'. The other thirteen percent responded that they did not participate because their class fellows might laugh at them. 
9. Do you participate when your Mother Tongue is used in the classroom?

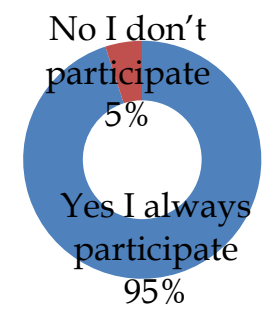

- Yes I always participate

no I don't participate

No, because my teacher encourages English

Ninety five percent of the participants, in both public and private secondary schools, participated when their Mother Tongue was used as language of instruction in the classroom. Only five percent of the participants told that they did not participate in such discussions. And no participant put a check on 'no because my teacher encourages English'.

10. Which language do you use while explaining science and other topics in the classroom?

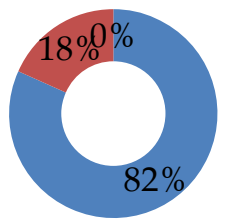

$$
\begin{aligned}
& \text { I explain in my Mother } \\
& \text { Tongue } \\
& \text { I explain in English } \\
& \text { I explain in Urdu }
\end{aligned}
$$

The findings show that Mother Tongue was used in explaining science and other topics in the classroom. Eighty two percent of the participants, both in public and private schools, responded that they explained in their Mother Tongue rather than English or Urdu. Some eighteen percent said that they explained science and other topics in English language. None of the participants used Urdu to explain such topics in the classroom.

\section{Do you speak English at your home?}

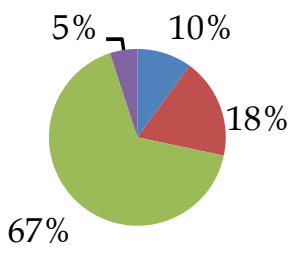

Yes, I always speak English at my home.

No, I never speak English at my home.

The above question was asked to know the participants' use of English outside the classroom. The findings show that the majority of the participants in both public and private schools responded 'Yes, sometimes I speak English at my home'. 
However, eighteen percent of the participants told that they never spoke English at their homes and ten percent were the participants who put a check on the option 'Yes, I always speak English at my home'. Five percent replied that they did not need to speak in English at their homes.

\section{Do your parents encourage you to speak in English at home?}

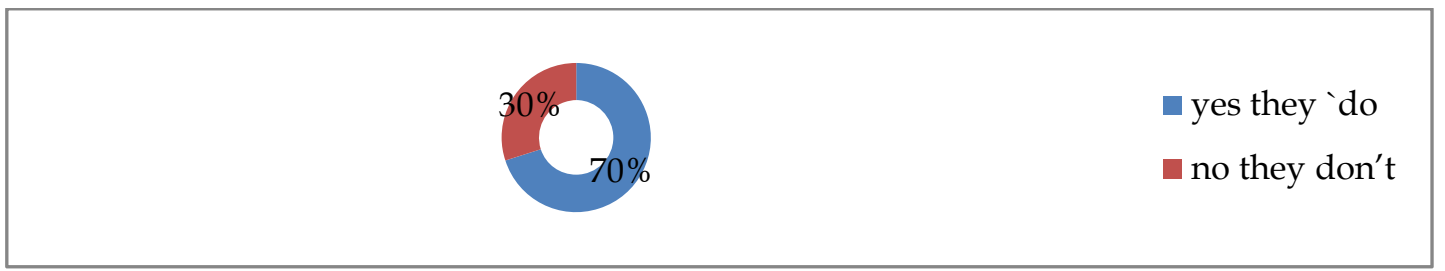

In response to the above question, the majority of the participants in both public and private schools responded that they were encouraged by their parents to speak English at their homes. However, thirty percent answered that they were not encouraged to speak English at their homes.

\section{Are your science course books written in your Mother Tongue?}

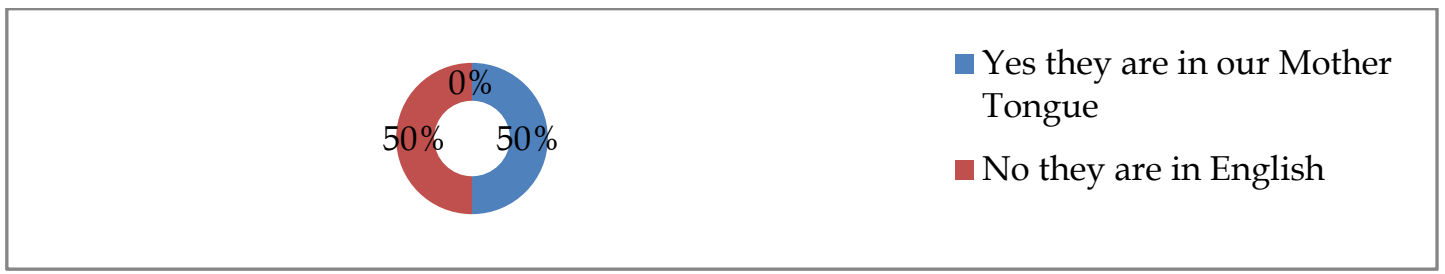

The diagram above shows the findings that the result was fifty-fifty because the language of instruction in both public schools was Sindhi and the science course books were written in the Mother Tongue. On the other hand, both private schools used English as language of instruction and the books were written in English.

\section{Which language of instruction do you follow when you take examination?}

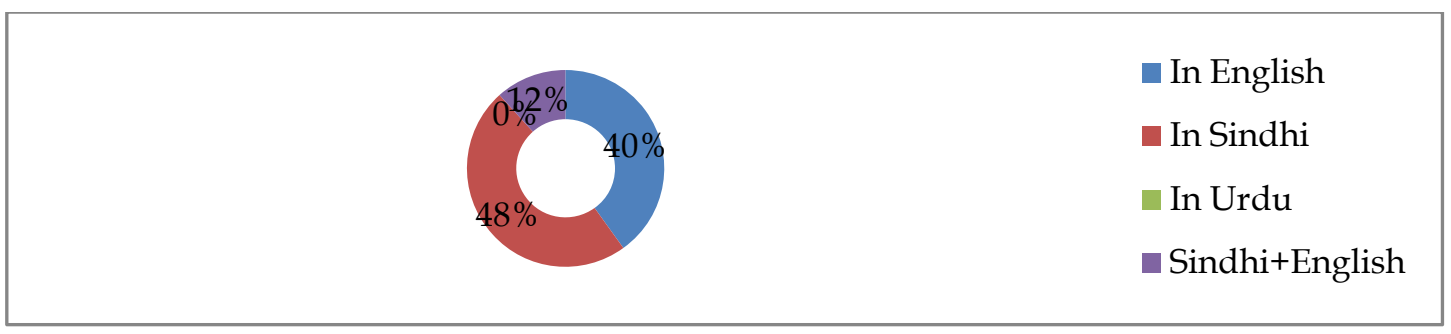

The above diagram shows that the majority of the participants of both public and private schools answered that they followed their Mother Tongue while taking examinations. Forty percent told that they used English and twelve percent said that they followed both English and Sindhi languages when they took examinations. 
15. What do you think should be the right Medium of Instruction?

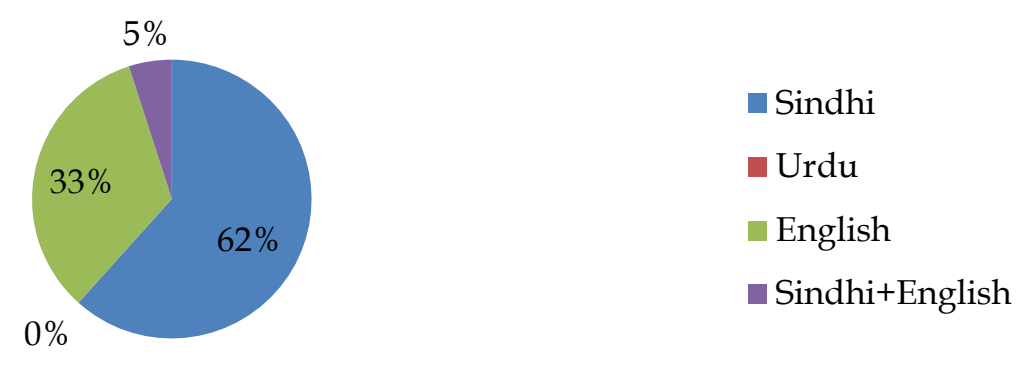

The findings of the above question show that the majority of the participants, both in public and private schools, suggested that the right medium of instruction should be the Mother Tongue in secondary education. Thirty three percent gave their idea that it should be English and five percent responded that it should be both Sindhi and English languages.

\section{Part II: Teacher Participants}

\section{Data Analysis of Teacher Participants' Background}

First, teacher participants' background information was analyzed. I have made a table to categorize the basic information of their background.

Table 5

Basic Information of the Teacher Participants

\begin{tabular}{|c|c|c|c|c|c|c|c|c|c|}
\hline \multirow{2}{*}{\multicolumn{2}{|c|}{$\begin{array}{c}\text { First } \\
\text { Language }\end{array}$}} & \multirow{2}{*}{\multicolumn{2}{|c|}{$\begin{array}{c}\text { Class } \\
\text { teaches }\end{array}$}} & \multirow{2}{*}{\multicolumn{2}{|c|}{ Gander }} & \multicolumn{2}{|c|}{$\begin{array}{l}\text { Primary Education } \\
\text { received from? }\end{array}$} & \multicolumn{2}{|c|}{$\begin{array}{l}\text { Current language } \\
\text { of Instruction }\end{array}$} \\
\hline & & & & & & \multirow{2}{*}{$\begin{array}{c}\text { Public } \\
\text { School } \\
6\end{array}$} & \multirow{2}{*}{$\begin{array}{c}\text { Private } \\
\text { School } \\
2\end{array}$} & \multirow{2}{*}{$\begin{array}{l}\text { Public } \\
\text { School } \\
\text { Sindhi } \\
\end{array}$} & \multirow{2}{*}{$\begin{array}{l}\text { Private } \\
\text { School } \\
\text { English }\end{array}$} \\
\hline Sindhi & 8 & $9^{\text {th }}$ & $10^{\text {th }}$ & Male & Female & & & & \\
\hline Balochi & 0 & 5 & 3 & 7 & 1 & & & & \\
\hline Punjabi & 0 & & & & & & & & \\
\hline Urdu & 0 & & & & & & & & \\
\hline Siraiki & 0 & & & & & & & & \\
\hline Total & & & & & 8 & & & & \\
\hline
\end{tabular}

The above table shows that the majority of the teacher participants in public and private schools in Sehwan responded that their Mother Tongue was Sindhi. However, only $1 \%$ was there whose Mother Tongue was Seraiki. No teacher's Mother Tongue was found Punjabi, Balochi, Urdu etc. in the study. The majority of the participants told they received their primary education from public schools as it can be seen in the bar chart. Eighty percent of the participants received their primary education from public schools and the twenty percent of the participants received their primary education from private schools. 
It is clear in the above table that the medium of instruction which was used in the teacher participants' primary education in both public and private schools was seventy five percent Sindhi and twenty five percent English. That shows that the majority of the participants were primarily educated in Sindhi as a medium of instruction which was their Mother Tongue.

The findings show in the above table that the majority of the teacher participants were multilingual. Thirty eight percent participants knew four languages and thirty seven percent of the participants knew three languages. Moreover, twenty five percent were the participants who spoke two languages and no participant was monolingual.

\section{Discussion and Findings of Part-Ii (Main Part)}

1. What language do you use when you teach science and other topics in the classroom?

\begin{tabular}{|ll|}
\hline & \\
& I use English \\
& I use Sindhi \\
& u Urdu \\
& Both \\
\hline
\end{tabular}

The majority of the teacher participants responded that they used Sindhi while teaching science and other topics in the classroom. However, thirteen percent of them used both Sindhi and English. On the other hand, twelve percent replied that they used only English to teach science and other topics in the classroom.

\section{Do you interact with your students in English?}

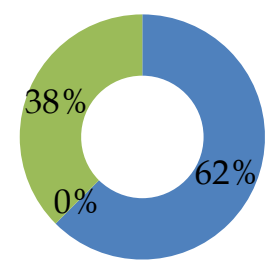

Yes, I do

No I do not

- Yes I do sometimes

In the findings of question number 2, the chart clearly shows that the majority of the participants of both public and private schools replied that they interacted with their students in English in the classroom. However, thirty eight percent of them said that they sometimes interacted in English in the classroom. No participants refused to interact in English with his students. 


\section{Do you feel easy when you interact with your students in English?}

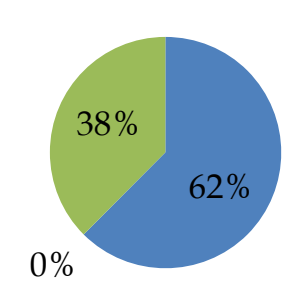

Yes it is easy

No, I feel difficult

The majority of the teacher participants felt easy while interacting with their students in English in both private and public schools. However, thirty eight percent of the participants responded that they felt it was difficult for them to make their students' concept clear about the topic in English.

\section{Do you use English while explaining science and other topics in the classroom?}

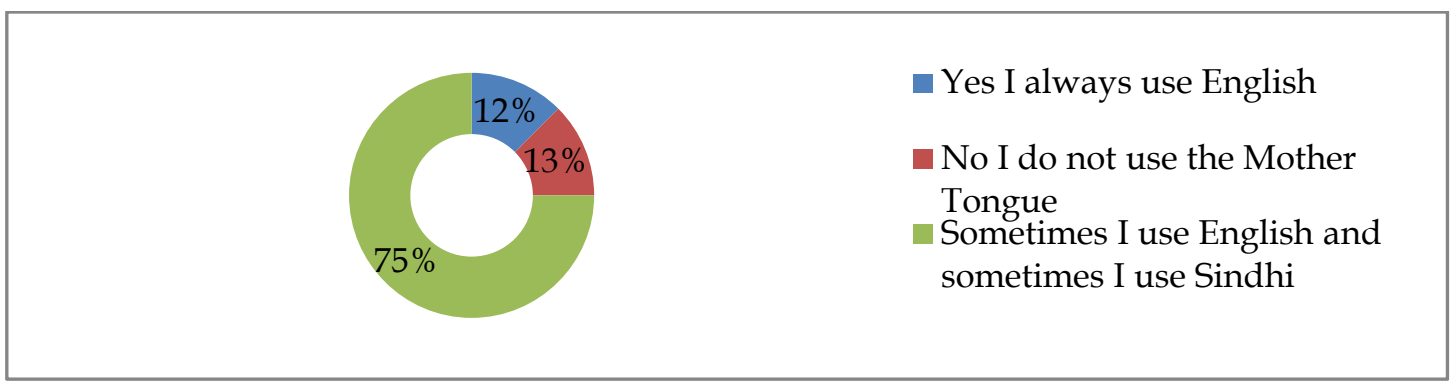

The findings in the above diagram show that the majority of the teacher participants in both public and private schools sometimes used English and sometimes the Mother Tongue while explaining science and other topics in the classroom. The teachers needed to shift from English to their Mother Tongue to make their students' concept clear about the topics. However, twelve percent responded that they always used English in the class and thirteen percent put a check on 'No, I don't use the Mother Tongue'.

\section{Which language do you use while explaining science topics in the classroom?}

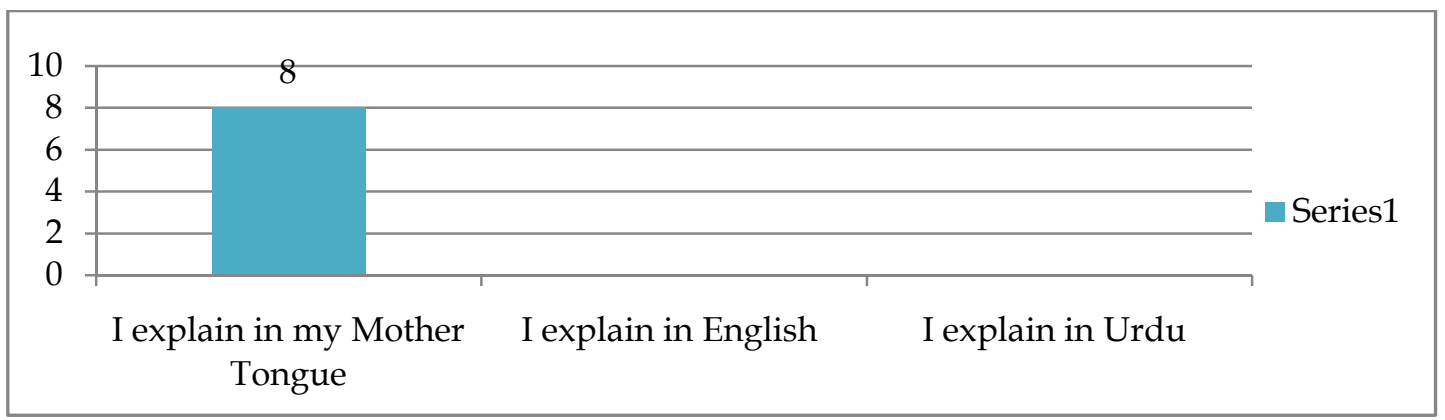


All the participants in both public and private schools used their mother tongue to explain science and other topics. None of the participants used Urdu or English.

\section{Do your students participate when English is used in the classroom?}

\begin{tabular}{|l|l|} 
& Yes they do \\
& $\begin{array}{l}\text { They want to participate but } \\
\text { they feel difficult } \\
\text { No they do not. }\end{array}$ \\
&
\end{tabular}

In response to the above question, the findings show in the above diagram that the result is fifty-fifty in both public and private schools. Some teachers claimed that their students do participate in such discussion where English is used. However, fifty percent of the participants told that the students do not want to participate because they feel it difficult to speak English in the classroom.

\section{Do your students participate when the Mother Tongue is used in the classroom?}

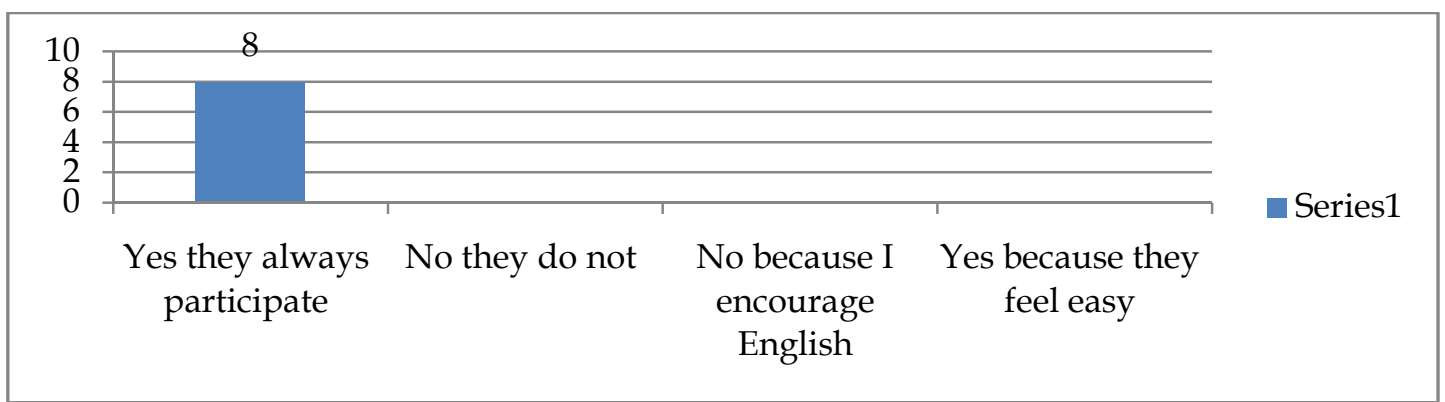

Students always participate in such discussions where their Mother Tongue is used. There was no any participant from both types of schools who could deny that the students do not participate in such discussion.

8. In which language of instruction, it is easy for your students to understand science and other topics in the classroom?

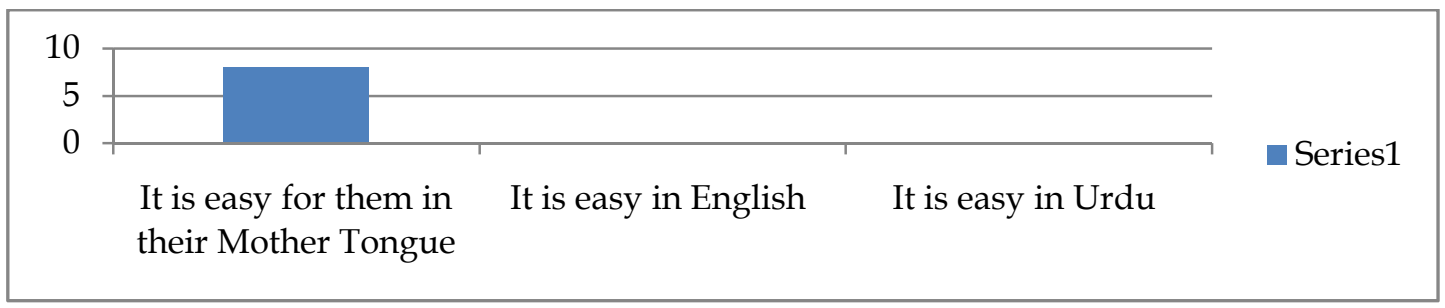


The participants of both public and private schools responded clearly that it was easy for their students to understand science and other topics in their Mother Tongue rather than any other language. On the other hand, no teacher responded that it was easy for them in English or Urdu as the above chart shows.

\section{Do you speak English at your home?}

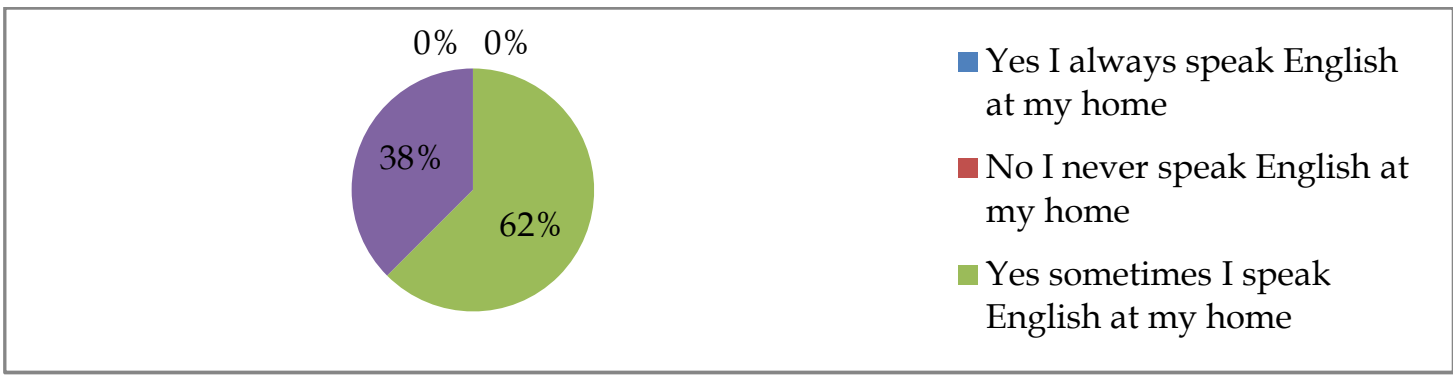

The majority of them responded that they spoke English at their homes sometimes. However, thirty eight percent of them responded that they did not need to speak English at their homes.

10. Do you speak English with your students outside of the classroom?

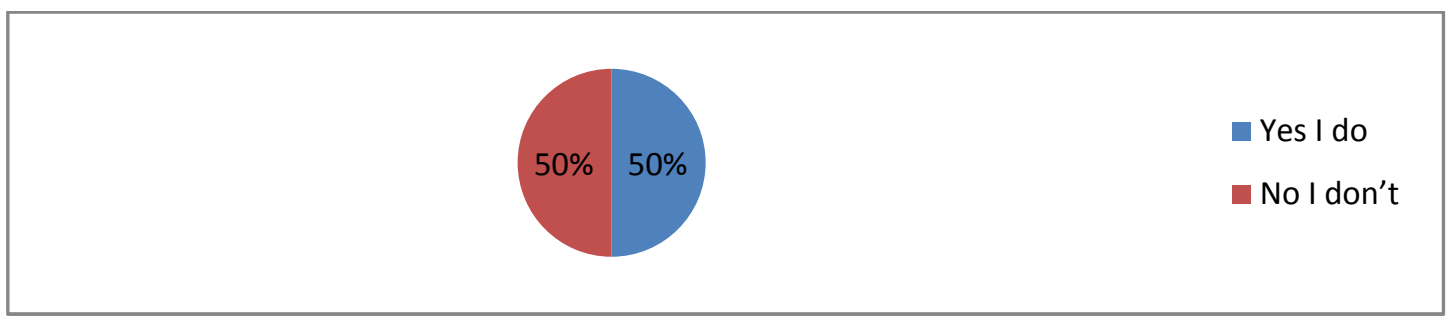

The findings in above pie chart show the response of the participants of both public and private schools in Sehwan that fifty percent said yes they spoke English with their students outside the classroom. However, fifty percent of them said that they did not speak outside the classroom.

\section{Are science course books written in students' Mother Tongue?}

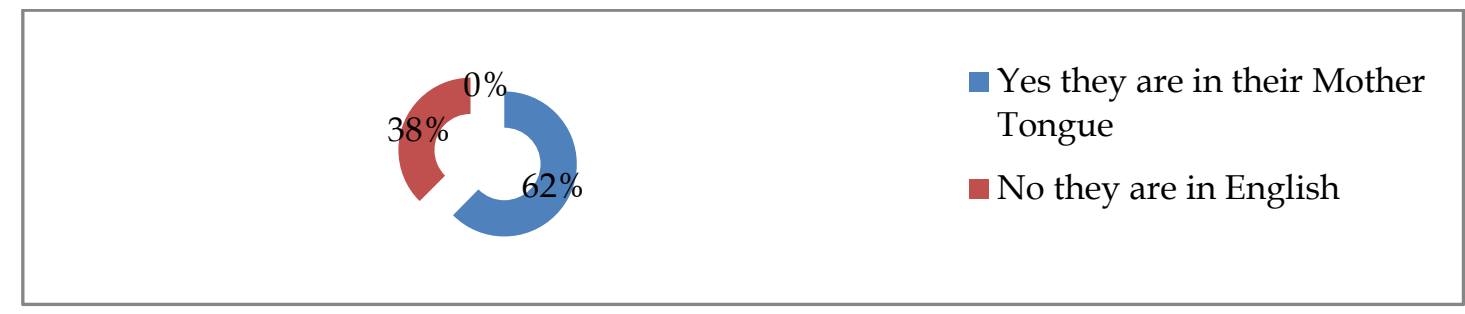

The majority of the participants replied that the course books were written in students' Mother Tongue. However, thirty eight percent of the participants 
responded that the course books were not written in the Mother Tongue. None of the participants said Urdu because it was not Mother Tongue of the students in Sehwan.

12. In which language of instruction students are examined?

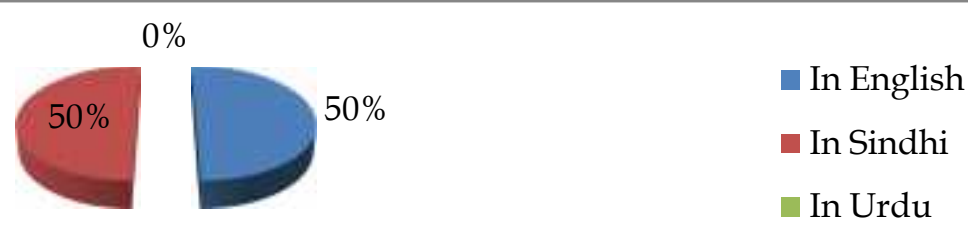

The above diagram shows the findings of above asked question that the response was fifty-fifty about English and Sindhi languages, because in two public secondary schools the medium of instruction was Sindhi, which is why the students were examined in Sindhi. However, in both private secondary schools, the medium of instruction was English, that is because they were examined in English.

13. What do you think the right language of instruction?

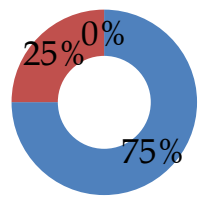

Sindhi

English

Urdu

When the participants were asked the above question their response as the findings show in above diagram that seventy five percent of the participants from both public and private secondary schools responded that the right medium of instruction should be their Mother Tongue. On the other hand, twenty percent of the teacher participants opined that it should be English. None of the participant chose Urdu as option.

\section{Part II: Teacher Participants}

\section{Data Analysis of Teacher Participants' Background}

First, teacher participants' background information was analyzed. I have made a table to categorize the basic information of their background.

Table 5

Basic Information of the Teacher Participants

\begin{tabular}{cccc}
$\begin{array}{c}\text { First } \\
\text { Language }\end{array}$ & $\begin{array}{c}\text { Class } \\
\text { teaches }\end{array}$ Gander & $\begin{array}{c}\text { Primary Education } \\
\text { received from? }\end{array}$ & $\begin{array}{c}\text { Current } \\
\text { language of } \\
\text { Instruction }\end{array}$ \\
\hline
\end{tabular}




\begin{tabular}{|c|c|c|c|c|c|c|c|c|c|}
\hline & & & & & & $\begin{array}{l}\text { Public } \\
\text { School }\end{array}$ & $\begin{array}{l}\text { Private } \\
\text { School }\end{array}$ & $\begin{array}{l}\text { Public } \\
\text { School }\end{array}$ & $\begin{array}{l}\text { Private } \\
\text { School }\end{array}$ \\
\hline Sindhi & 8 & $9^{\text {th }}$ & $10^{\text {th }}$ & Male & Female & 6 & 2 & Sindhi & English \\
\hline Balochi & 0 & 5 & 3 & 7 & 1 & & & & \\
\hline Punjabi & 0 & & & & & & & & \\
\hline Urdu & 0 & & & & & & & & \\
\hline Siraiki & 0 & & & & & & & & \\
\hline Total & & & & & 8 & & & & \\
\hline
\end{tabular}

1. What is your Mother Tongue?

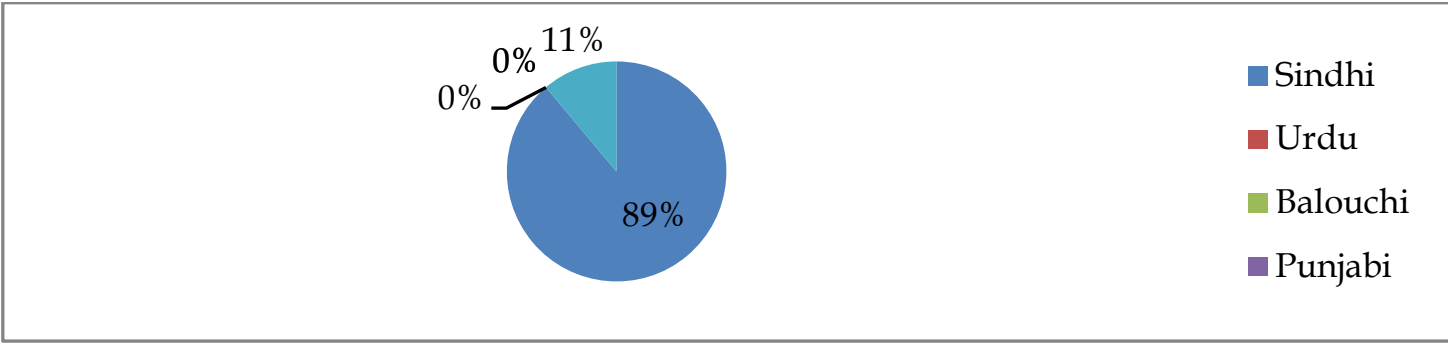

The pie chart above shows that the majority of the teacher participants in public and private schools in Sehwan responded that their Mother Tongue was Sindhi. However, only one participant was there whose Mother Tongue was Seraiki. No teacher's Mother Tongue was found Punjabi, Balochi, Urdu etc. in the study.

\section{Where did you receive you primary education?}

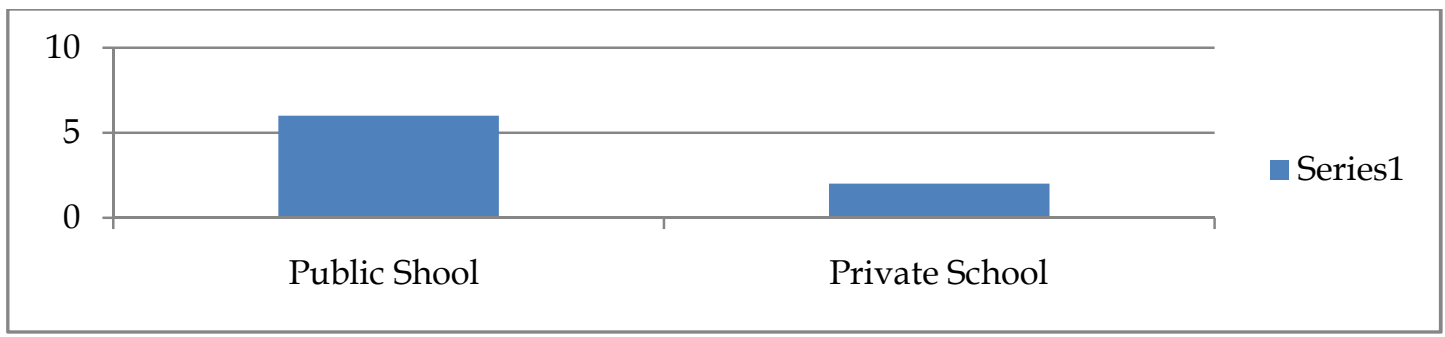

In response to the above question, the majority of the participants told they received their primary education from public schools as it can be seen in the bar chart. Eighty percent of the participants received their primary education from public schools and the twenty percent of the participants received their primary education from private schools.

\section{What was the Medium of Instruction in the Primary education?}




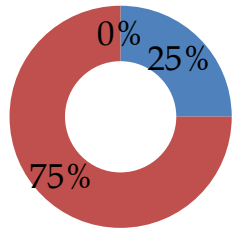

English

- Sindhi

Urdu

The above diagram shows that the medium of instruction which was used in the teacher participants' primary education in both public and private schools was seventy five percent Sindhi and twenty five percent English. That shows that the majority of the participants were primarily educated in Sindhi as a medium of instruction which was their Mother Tongue.

\section{How many languages did the participants already know?}

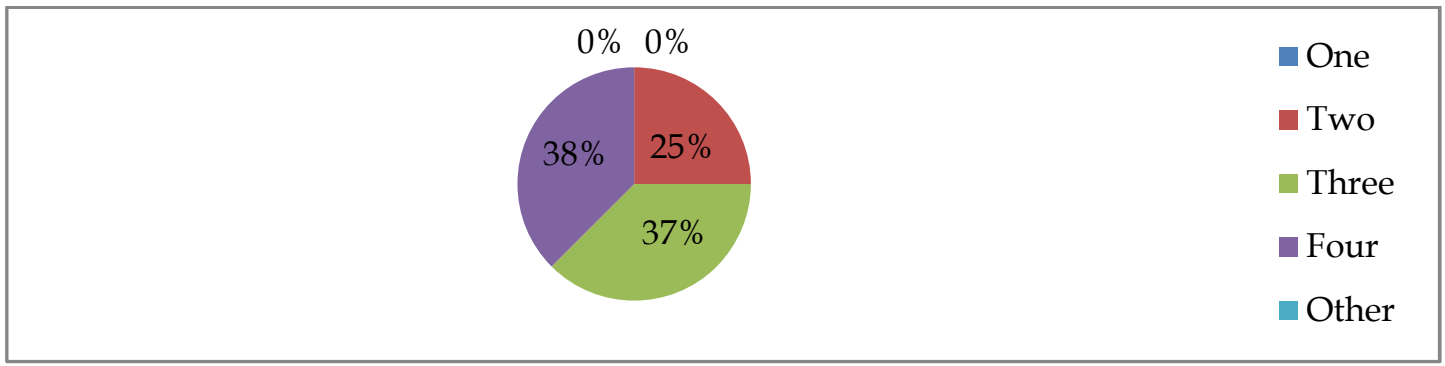

The diagram above shows the responses to the language background while studying in secondary school; the findings show that the majority of the teacher participants were multilingual. Thirty eight percent participants knew four languages and thirty seven percent of the participants knew three languages. Moreover, twenty five percent were the participants who spoke two languages and no participant was monolingual.

\section{Discussion and Findings of Part-II (Main Part)}

1. What language do you use when you teach science and other topics in the classroom?

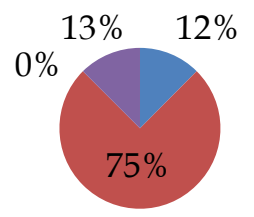

$$
\begin{aligned}
& \text { - I use English } \\
& \text { I use Sindhi } \\
& \text { — Urdu }
\end{aligned}
$$

The majority of the teacher participants responded that they used Sindhi while teaching science and other topics in the classroom. However, thirteen percent 
of them used both Sindhi and English. On the other hand, twelve percent replied that they used only English to teach science and other topics in the classroom.

\section{Do you interact with your students in English?}

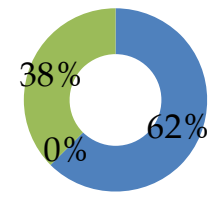

Yes, I do

- No I do not

Yes I do sometimes

In the findings of question number 2, the chart clearly shows that the majority of the participants of both public and private schools replied that they interacted with their students in English in the classroom. However, thirty eight percent of them said that they sometimes interacted in English in the classroom. No participants refused to interact in English with his students.

\section{Do you feel easy when you interact with your students in English?}

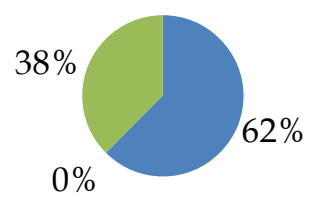

Yes it is easy

The majority of the teacher participants felt easy while interacting with their students in English in both private and public schools. However, thirty eight percent of the participants responded that they felt it was difficult for them to make their students' concept clear about the topic in English.

4. Do you use English while explaining science and other topics in the classroom?

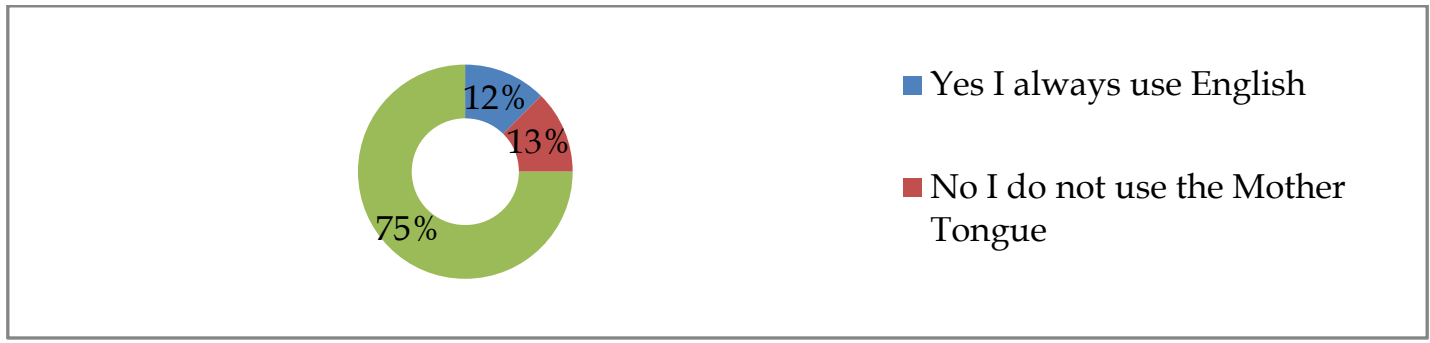

The findings in the above diagram show that the majority of the teacher participants in both public and private schools sometimes used English and sometimes the Mother Tongue while explaining science and other topics in the classroom. The teachers needed to shift from English to their Mother Tongue to make their students' concept clear about the topics. However, twelve percent 
responded that they always used English in the class and thirteen percent put a check on 'No, I don't use the Mother Tongue'.

5. Which language do you use while explaining science topics in the classroom?

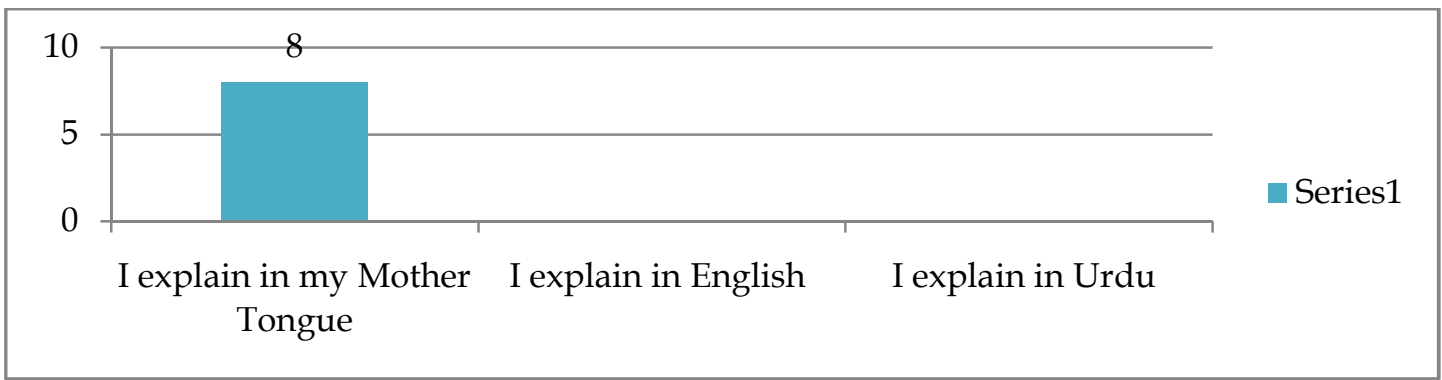

All the participants in both public and private schools used their mother tongue to explain science and other topics. None of the participants used Urdu or English.

6. Do your students participate when English is used in the classroom?

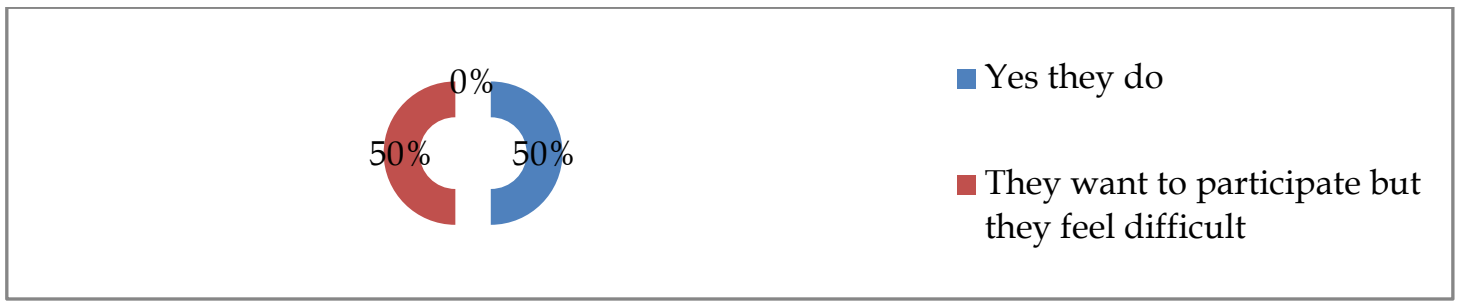

In response to the above question, the findings show in the above diagram that the result is fifty-fifty in both public and private schools. Some teachers claimed that their students do participate in such discussion where English is used. However, fifty percent of the participants told that the students do not want to participate because they feel it difficult to speak English in the classroom.

7. Do your students participate when the Mother Tongue is used in the classroom?

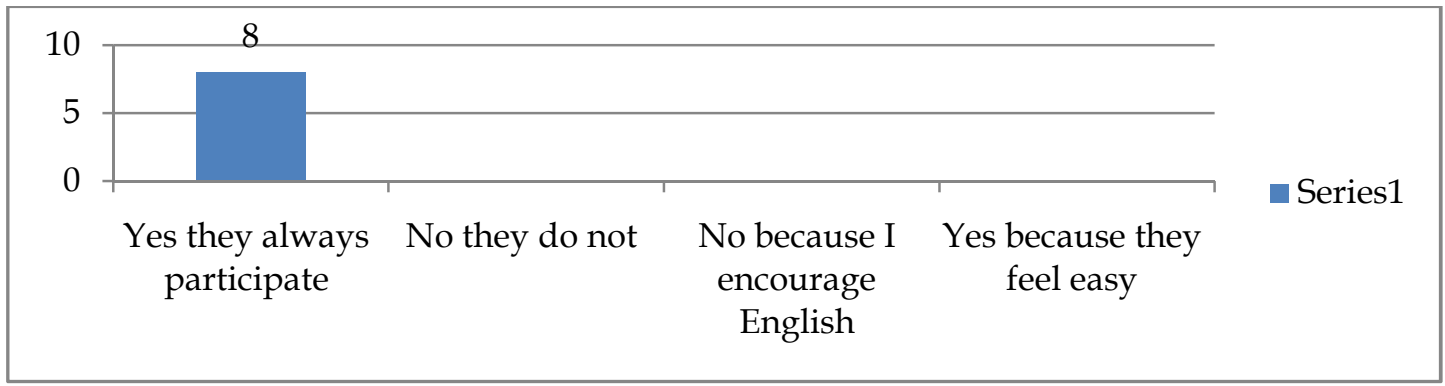


Students always participate in such discussions where their Mother Tongue is used. There was no any participant from both types of schools who could deny that the students do not participate in such discussion.

8. In which language of instruction, it is easy for your students to understand science and other topics in the classroom?

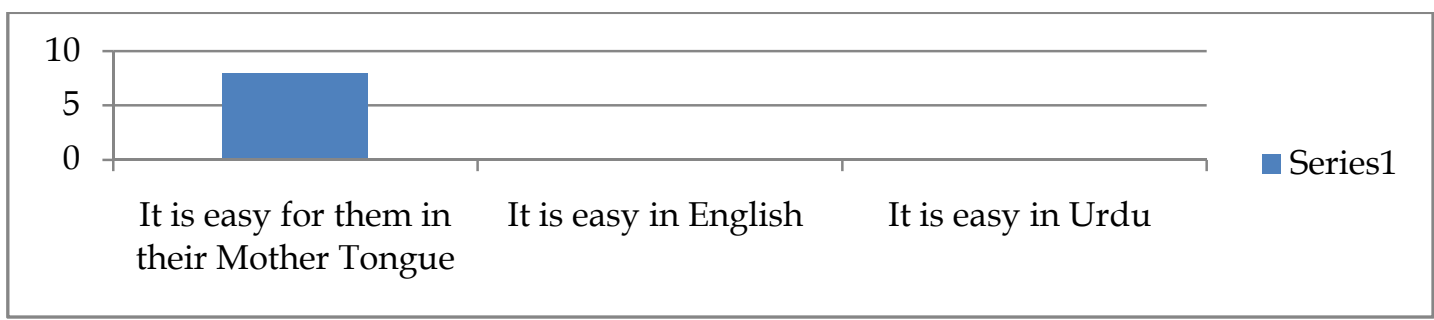

The participants of both public and private schools responded clearly that it was easy for their students to understand science and other topics in their Mother Tongue rather than any other language. On the other hand, no teacher responded that it was easy for them in English or Urdu as the above chart shows.

\section{Do you speak English at your home?}

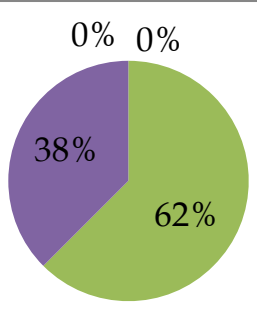

- Yes I always speak English at my home

- No I never speak English at my home

- Yes sometimes I speak English at my home

The majority of them responded that they spoke English at their homes sometimes. However, thirty eight percent of them responded that they did not need to speak English at their homes.

10. Do you speak English with your students outside of the classroom?

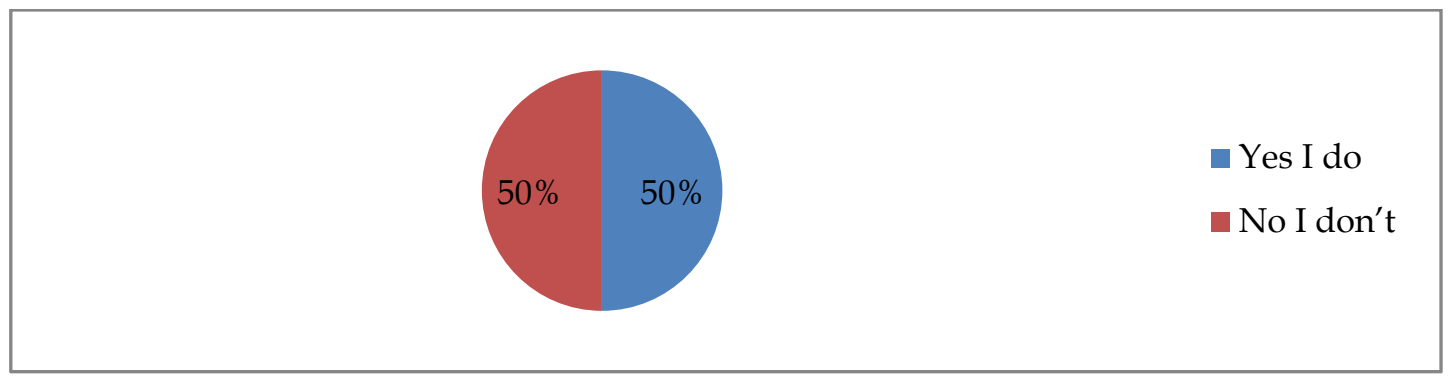

The findings in above pie chart show the response of the participants of both public and private schools in Sehwan that fifty percent said yes they spoke English 
with their students outside the classroom. However, fifty percent of them said that they did not speak outside the classroom.

\section{Are science course books written in students' Mother Tongue?}

\begin{tabular}{|l|l|} 
& Yes they are in their Mother \\
& Tongue \\
& No they are in English \\
& No they are in Urdu
\end{tabular}

The majority of the participants replied that the course books were written in students' Mother Tongue. However, thirty eight percent of the participants responded that the course books were not written in the Mother Tongue. None of the participants said Urdu because it was not Mother Tongue of the students in Sehwan.

12. In which language of instruction students are examined?

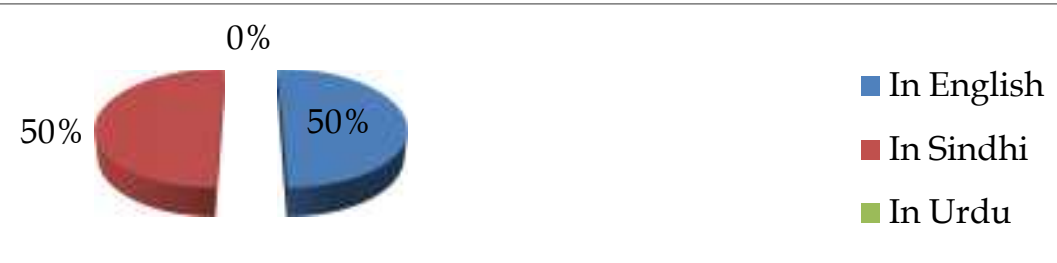

The above diagram shows the findings of above asked question that the response was fifty-fifty about English and Sindhi languages, because in two public secondary schools the medium of instruction was Sindhi, which is why the students were examined in Sindhi. However, in both private secondary schools, the medium of instruction was English, that is because they were examined in English.

\section{What do you think the right language of instruction?}

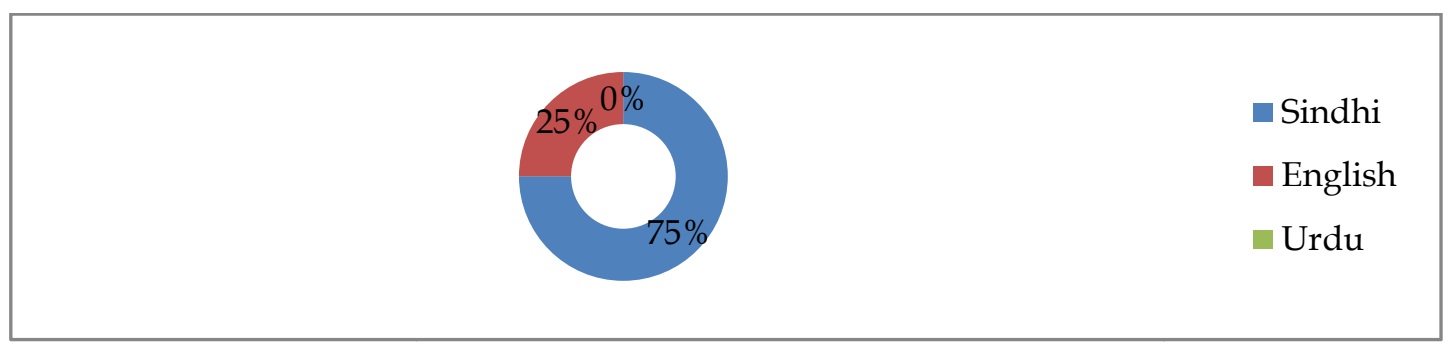

When the participants were asked the above question their response as the findings show in above diagram that seventy five percent of the participants from both public and private secondary schools responded that the right medium of 
instruction should be their Mother Tongue. On the other hand, twenty percent of the teacher participants opined that it should be English. None of the participant chose Urdu as option.

\section{Discussion and Conclusion}

The study investigates the role of Mother Tongue in public and private schools in Sehwan, district Jamshoro. The study proposed to respond the following research questions:

1. How does the use of mother tongue as medium of instruction impact the teaching process in secondary schools in Sehwan?

2. Which medium of instruction is used in science and arts subjects?

3. Which language teachers and students prefer for instruction?

Addressing the above research questions, quantitative data was collected and analyzed after developing and distributing two types of questionnaire. A questionnaire was designed for the student participants and another questionnaire was designed for teacher participants. Both of these types of questionnaires were distributed among the 60 student participants and 8 teacher participants. Data was collected and analyzed from both types of the participants.

the main findings from both types of participants are presented below.

\section{- Role of Mother Tongue in study}

The study found that students in private schools were supposed to study through English medium because they did not have any choice. The students expressed their thoughts that they might study more comfortably in their Mother Tongue. Apart from that, the teachers also responded that they also used the Mother Tongue in the classroom feeling more comfortable and easier with it.

\section{- Role of Mother Tongue in classroom interaction}

The role of Mother Tongue was found very significant in the classroom interaction in private schools. The interaction into the classroom was discovered as student-to-student and student-to-teacher or teacher-to-students. Occasionally students and teachers used English to explain some scientific terminology because they did not find any word form their Mother Tongue and the concept which was thought to be memorized as it was written in the book in English. Another reason of interacting in the Mother Tongue was that many of the students did not have competence of English language and some of them felt hesitation while speaking English before their fellow students in the classroom. However, some of them expressed that they interacted with their teacher in English language. Furthermore, the majority used the Mother Tongue while interacting in the classroom. The main 
cause behind that might be the rural background of learners in which they had minimal opportunities of exposure to English language. Hence, students were not aware of the benefits of learning English. Passing subjects was appeared to be preferred rather than gaining the mastery of English language.

\section{- Role of Mother Tongue in understanding the topics}

Except a few students, majority of the students were able to understand through the Mother Tongue in both public and private schools. Some students responded that they have their concepts clear on the topic by their parents in their Mother Tongue when they get their homes. The cause maybe that the student had not sufficient competence of English. Teachers also pointed out that using the Mother Tongue they made their students' concepts clear about the topics which is because majority of students were not good at English language. Apart from that, teachers themselves were seen to be comfortable using the Mother Tongue to explain the topics in the classroom.

\section{- Role of Mother Tongue in Classroom Participation}

The role of Mother Tongue in classroom participation was found very fundamental in both public and private secondary schools in Sehwan. The Mother Tongue was found to be used in classroom. Students felt difficult to take participation in activities in which English was used. In sufficient knowledge of English could be the reason of not taking part in classroom activities. The teachers also gave their opinion that students get interested in the discussion when the Mother Tongue is used in such activities in the classroom. Apart from that, when the students were asked to take participation in the discussion in the classroom, they hesitated and some of them refused to take part. Obviously, the reason seems to have lack of competence in English language.

\section{- Role of Mother Tongue in explanation}

The role of the Mother Tongue in explanation of science and other topics was found very significant in the study except a few of the student who expressed they prefer to use English in explanation. The majority of the students explained science and other topics using the Mother Tongue in the classroom. Besides, the teachers also expressed that the students explain the mentioned topics in their Mother Tongue. The use of Mother Tongue in explanation in the classroom might be because of feeling more comfortable rather than using English language.

\section{- Role of Mother Tongue in examination}

The medium of instruction in examination was found Mother Tongue in public schools. Students had choice to write in their Mother Tongue (Sindhi or Urdu). However, in private schools, English was used in examination. The students did not have a choice. They were supposed to write their exams in English. When 
the students were asked whether they would feel comfortable if they took exams in their Mother Tongue every participant responded positively. Further, some of the student participants expressed that first they had to gather their ideas in the Mother Tongue and then they translate them into English in the examination. The reason can be the lack of competence in English language. Teachers also gave their opinion that if the Mother Tongue was used in the exams, students might feel comfortable writing the answers.

\section{- Role of Mother Tongue in Secondary Schools}

In this study, the teacher participants and student participants expressed their views that the Mother Tongue should be the medium of instruction in secondary schools in Sehwan. However, a few of students opined that there should be English language.

The role of the Mother Tongue was found very fundamental in secondary education. The participants preferred to use the Mother Tongue and also the teachers used the Mother Tongue when they taught to the students in the classroom. The main point of using Mother Tongue in secondary school education in Sehwan is that the students had not English competence which is why they felt difficulty in classroom participation and taking part in discussions. Students also felt hesitation in classroom interaction if the English was used. Hence, students felt more comfortable when the Mother Tongue was used in all activities in classroom when they were being taught science and other topics. Therefore, the Role of the Mother Tongue was found very significant in classroom participation, classroom interaction, understanding the science and other topics and in examinations. 


\section{References}

Ahmed, S. A. (2011). Issue of Medium of Instruction in Pakistan.International Journal of Social Sciences and Education. Vol. 1, Issue 1, January 2011.

Andrabi, T. R. \& Das, J. \&Khuwaja, A. A. (2010). Education Policy in Pakistan: A framework for Reform. International Growth Center - Pakistan.

Arghode, V. (2012).Qualitative and quantitative research: Paradigmatic differences. Global Education Journal, 2012(4), pp.155-163.

Attride-Stirling, J. (2001). Thematic networks: An analytic tool for qualitative research. Qualitative Research, 1 (3), pp. 385-405.

Bakhri, M. S. (1019). Tareekh-e-Masoomi.Behndarkar Institute, Poona.

Bascoli, A. (2008).A Discussion on Using English Medium of Instruction in Hong Kong and the Sociolinguistic Impacts. LCOM Papers 1, 37-51.

Bengali, K. (1999). History of Educational Policy Making and Planning in Pakistan.A publication of the Suitable Development Policy Institute (SDPI).

Biesta, G. (2010). 'Pragmatism and the philosophical foundations of mixed methods research', In: Teddlie, C. ETashakkori,A . (Eds) Sage handbook of mixed methods in social and behavioral research. California: Sage Publications.2nd edition (pp. 95-118).

Braun, V. \& Clarke, V. (2006).Using thematic analysis in psychology. Qualitative Research in Psychology, 3 (2), pp. 77-101.

Bryman, A. \&Bell, E. (2011).Business research methods.3rd edn.Oxford: Oxford University Press.

Chang, Y. (2010). English Medium Instruction for Subject Courses in Tertiary Education: Reactions from Taiwanese Undergraduate Students. Taiwan International ESP Journal, Vol. 2,: 1, 55-84.

Charles, O. W. (2015). The Use of English as a Medium of Instruction at the Upper Basic Level (Primary four to Junior High School) in Ghana: From Theory to Practice. Journal of education and practice.Vol. 6, No. 3 .

Creswell, J. W. \& Plano Clark, V. L. (2007). Designing and conducting mixed methods research; Thousand Oaks, California: Sage Publications.

Creswell, J. W. \& Plano Clark, V. L. P. (2011). Designing and conducting mixed methods research.Sage Publications.2nd edn. Thousand Oaks, California. 
Creswell, J. W. (2003). Research design: Qualitative, quantitative, and mixed methods approaches, 2nd edn. Thousand Oaks, California: Sage Publications.

Creswell, J. W. (2009). Research design: Qualitative, quantitative, and mixed methods approaches, 3rd edn. Thousand Oaks, California: Sage Publications.

Creswell, J. W. (2013). Research design: Qualitative, quantitative, and mixed methods approaches, 4th edn. Thousand Oaks, California: Sage Publications.

Dawn, R. (2012). The Effects of English Medium Instruction on Language Proficiency of students enrolled in Higher Education in the UAE. University of Exeter.

Deniz, N. K. \& Lincoln, Y. S. (2005.The discipline and practice of qualitative research, In: N. K Denzin\& Y. S Lincoln, (Eds) The sage handbook of qualitative research 3rdedn. London: Sage Publication.

Dörnyei, Z. (2007). Research methods in applied linguistics: Quantitative, qualitative, and mixed methodologies. Oxford: Oxford University Press.

Dr. Ahmed, A. (2013). The Role of Medium of Instruction used in Pakistani Classrooms. Interdisciplinary Journal of Contemporary Research Business.Vol. 4 No. 12.

Gautam, V. (2003). Education of Tribal Children in India and the Issue of Medium of Instruction: A Jhanshala Experience. ZENITH International Journal of Business Economics \& Management Research Vol.1 Issue 2, Nov 2011, ISSN 22498826.

Grinnell Jr, R. M. EUnrau, Y. A. (2010). Social work research and evaluation: Foundations of evidence-based practice. Oxford: Oxford University Press.

Kangas, S. T. (2011). Multilingualism.New Fetter Lane, London EC4P 4EE.

Kangas, S.T \&Robert, P. (2000) “Linguistics human rights"; Berlin; New York.

Madhavan, D. (2014). English Medium of Instruction (EMI) Philosophies and Policies, Ecole Center Paris.

Mahboob, A. (2009). English as an Islamic language: A case study of Pakistani English. World Englishes, 28(2), pp.175-189.

Mayari, C. (2007). What Role Does the Language of Instruction Play for Successful Education? A case study of the impact of language choice a Namibian school.School of Humanities.

Miles, M. B. \& Huberman, A. M. (1994).Qualitative Data analysis: An expanded

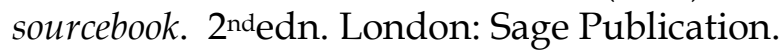


Morell, T. (2012).English as the Medium of Instruction: A response to internationalization.University of Alecante.

Morse, J. M. (2004). Principles of mixed methods and multimethod research design. Thousand Oaks. California: Sage Publications.

Nha T. T. Vu (2014). English as a Medium of Instruction: Challenges for Vietnamese Tertiary Lecturers. The Journal of Asia TEFL Vol. 11. No. 3, pp. 1-31.

Onwuegbuzie, A. \& Leech, N. (2005).Taking the " $q$ " out of research: Teaching research methodology courses without the divide between quantitative and qualitative paradigms. Quality \& Quantity, 39(3), pp.267-296.

Onwuegbuzie, A. J. \& Leech, N. L. (2007).Sampling designs in qualitative research: Making the sampling process more public. Qualitative Report. Creative Common License 12(2), pp.238254.

Punch, K. f. (2013).Introduction to social research: Quantitative and Qualitative approaches, 3 rdedn;London: Sage Publication.

Rahman, T. (2002).Language Ideology and Power: Language-learning among the Muslims of Pakistan North India. Oxford University Press.

Rehman T. (2006) Language and politics in Pakistan; Oxford University Press 1996

Ruth. M. H. Wong (2010). The Effectiveness of using English as the Sole Medium of Instruction in English Classes: Student Responses and Improved English Proficiency. Porta Linguarum 13, enro pp. 119-130.

Sean O'H. (2000). English Medium Secondary Schools: Privileged Orphans in the SAR. Intercultural Communication Studies. X: 2, 2000.

Tashakkori, A. \&Teddlie, C. (1998).Mixed methodology: Combining qualitative and quantitative approaches. California: Sage Publications.

Teddlie, C. \&Tashakkori, A. (Eds.) (2009).Foundations of mixed methods research: Integrating quantitative and qualitative approaches in the social and behavioral sciences. California: Sage Publications.

Thativi, M. A. S. (2006). Tuhfat-ul-Kiram.3rd edn. Sindhi Adabi Board, Jamshoro

UNESCO, (1994-2003), Linguistic Human Rights, www.unesco.org

UNESCO, (2011).Mother Tongue-based Bilingual or Multilingual Education in the Early Years.Jessica Ball University of Victoria. 